\title{
Effect of tigernut based diets on haematology and serum biochemistry of broiler finisher
}

\author{
${ }^{*}$ Agbabiaka . L. A ${ }^{1}$, F.N. Madubuike ${ }^{1}$, B.U. Ekenyem ${ }^{1}$ and B.O Esonu ${ }^{2}$ \\ ${ }^{1}$ Department of Animal Science and Fisheries, Imo State University, Owerri, Nigeria \\ ${ }^{2}$ Department of Animal Science, Federal University of Technology, Owerri, Nigeria \\ E-mail : adegokson2@yahoo.com
}

\begin{abstract}
An investigation was conducted to determine the effect of tigernut based diets on the haematology and serum characteristics of broiler finisher. Two hundred and twenty five broiler birds were assigned to the five experimental diets in which tigernut meal replaced maize at $0 \%$, $25 \%, 50 \%, 75 \%$ and $100 \%$ respectively at 45 birds per treatment which was further sub-divided into 3 replicates of fifteen birds each in a completely randomized design. Results indicated a decrease in haematological values of Packed cell volume, Haemoglobin, Red blood cell and Mean cell volume as tigernut increased in diets $(p<0.05)$ while white blood cell and lymphocyte values were directly proportional to the concentration of tigernut meal in the diets $(p<0.05)$. However, the serum values decreased with increased dietary inclusion of tigernut except creatinine and Urea $(p<0.05)$. There was no significant difference $(p>0.05)$ among the treatment groups for globulin, cholesterol and bilirubin. This study showed that tigernut meal cannot totally replace maize in broiler finisher diets but could be tolerated up to $50 \%$ dietary inclusion without compromising the physiological status of the birds.
\end{abstract}

Key words: Broiler finisher, tigernut meal, response, haematology and serum biochemistry.

\section{INTRODUCTION}

The major aim of animal nutritionist is to formulate diets that will enhance the performance of the livestock/fishes by supplying the nutrients needed for growth and production without necessarily compromising their physiological/health status. Many non-conventional feedstuffs such as tigernut have not been extensively used as monogastric feed component such as poultry and fish due to the inherent high fibre and anti-nutrients which includes Alkaloid, Tannins, Phytate, Trypsin inhibitors and Phytin Phosphorus (Oladele et al., 2009). These factors have been reported to be relatively deleterious to the animals particularly monogastrics fed diets containing such unprocessed or raw feedstuff(s) (David, 2009).

However, the present reality in third world countries to source for alternative energy sources to cereal based ingredients has necessitated the need to investigate the potentials of some other energy feedstuffs such as tigernut that are cheap and readily available with less competition with humans and beer-brewing industries compared to maize in fish and livestock nutrition. This will reduce the cost of feed and animal products such as meat and eggs among others for Nigerian populace.
The study on the changes in blood characteristics of livestock and fishes have been widely studied, particularly in regard to detecting the health status from diseased or stressed animals exposed to different toxicants and metabolic stress( Ezeri, 2001; Joshi et al., 2002; Osuigwe et al., 2005; Emenalom et al., 2009; Obidinma, 2009). Blood as a good indicator to determine the health of organisms is considered a vital tool in development of animal agriculture. This trial was designed to determine the effect of feeding graded levels of tigernut diets on the haematology and serum biochemistry of broiler finisher.

\section{MATERIALS AND METHODS}

Source and Processing of tigernut: The tigernuts used for the study was purchased from the open market at "AMA-HAUSA" in Owerri , Nigeria. The tigernut seeds were sundried for 5 days and passed through a hammer mill, to produce tigernut meal. The drying process was to reduce excess moisture so as to prevent rancidity of the material and growth of moulds.

Experimental diets: Five broiler starter experimental diets were formulated such that tigernut meal replaced maize at $0 \%, 25 \%, 50 \%, 75 \%$ and $100 \%$ dietary levels respectively. Other conventional feed 
ingredients such as Maize, fish meal, soya bean meal, wheat offal, bone meal, palm kernel meal (PKM), vitamin-premix, and salt were procured from Zion Farm Feed Mills, Egbu, Owerri, Imo State. A sample of tigernut meal and experimental diets were subjected to proximate analysis (Tables 1 and 2) using standard procedures according to AOAC, 1995. The tigernut meal was further subjected to phytochemical analysis for anti-nutritional inhibitors using standard methods (Table 3 ). Composition of experimental diets is presented on Table 4.
Table 1: Proximate composition of tigernut meal (\%DM)

\begin{tabular}{lc}
\hline Parameters & Concentration (\%) \\
\hline Moisture content & 7.62 \\
Crude protein & 8.44 \\
Ether extracts & 27.71 \\
Crude fiber & 11.69 \\
Ash & 3.51 \\
NFE & 41.03 \\
\hline
\end{tabular}

Table 2: Proximate analysis of the treatment diets fed broiler finisher chicks

\begin{tabular}{|c|c|c|c|c|c|}
\hline \multicolumn{6}{|c|}{ Dietary levels of Tigernut meal } \\
\hline & $0 \%$ & $25 \%$ & $50 \%$ & $75 \%$ & $100 \%$ \\
\hline Crude protein & 20.75 & 20.33 & 20.12 & 19.62 & 18.43 \\
\hline Crude fiber & 5.09 & 5.84 & 6.07 & 6.00 & 6.31 \\
\hline Ether extract & 4.26 & 5.05 & 5.74 & 6.01 & 6.81 \\
\hline Ash & 5.56 & 8.15 & 7.42 & 7.50 & 6.31 \\
\hline${ }^{*} \mathrm{ME}(\mathrm{Kcal} / \mathrm{kg})$ & 2809.42 & 2894.36 & 2979.72 & 3064.87 & 3250.02 \\
\hline \multicolumn{6}{|c|}{${ }^{*}$ ME = Metabolisable energy calculated } \\
\hline \multicolumn{6}{|c|}{ Phytochemistry of raw tigernut meal } \\
\hline Parameters & & & & & \\
\hline Tannin (\%) & & & & & \\
\hline Saponin (\%) & & & & & \\
\hline Phytate $(\mathrm{mg} / \mathrm{g})$ & & & & & \\
\hline Phytin Phytate $(\mathrm{mg} / \mathrm{g})$ & & & & & \\
\hline Phenols (\%) & & & & & \\
\hline
\end{tabular}

Table 4. Ingredients composition of the experimental diets fed broiler finishers

\begin{tabular}{llllll}
\hline Ingredients & $0 \%$ & $25 \%$ & $50 \%$ & $75 \%$ & $100 \%$ \\
\hline Maize & 52.00 & 39.0 & 26.00 & 13.00 & 0.00 \\
Tigernut meal & 0.00 & 13.00 & 26.00 & 39.00 & 52.00 \\
Soybean meal & 20.00 & 20.00 & 20.00 & 20.00 & 20.00 \\
Wheat offal & 10.00 & 10.00 & 10.00 & 10.00 & 10.00 \\
Fish meal & 2.00 & 2.00 & 2.00 & 2.00 & 2.00 \\
Palm kernel cake & 10.00 & 10.00 & 10.00 & 10.00 & 10.00 \\
Blood meal & 2.00 & 2.00 & 2.00 & 2.00 & 2.00 \\
Bone meal & 3.00 & 3.00 & 3.00 & 3.00 & 3.00 \\
Lysine & 0.25 & 0.25 & 0.25 & 0.25 & 0.25 \\
Methionine & 0.25 & 0.25 & 0.25 & 0.25 & 0.25 \\
Salt & 0.25 & 0.25 & 0.25 & 0.25 & 0.25 \\
Vit/Min.Premix & 0.25 & 0.25 & 0.25 & 0.25 & 0.25 \\
Total & 100.0 & 100.0 & 100.0 & 100.0 & 100.0 \\
Cost/25kg feed (N) & $\mathbf{2 0 5 6 . 5 0}$ & $\mathbf{2 0 1 7 . 5 0}$ & $\mathbf{1 9 7 8 . 5 0}$ & $\mathbf{1 9 3 9 . 5 0}$ & $\mathbf{1 9 0 0 . 5 0}$ \\
\hline
\end{tabular}

To provide the following per $\mathrm{kg}$ of diet:

Vit A; 1000lu; Vit D;2000 lu, Vit E; 5lu, Vitk, 2.5mg, Ribofiavin, $5.5 \mathrm{mg}$, vitamin $12,0.01 \mathrm{mg}$, vitamin $\mathrm{z}$, 
$0.01 \mathrm{mg}$ panthothenic acid; $6 \mathrm{mg}$, Nican, $5 \mathrm{mg}$, chlorinem 3mg, folic, $4 \mathrm{mg}, \mathrm{mn}, 8 \mathrm{mg}$, zn; $0.5 \mathrm{mg}$, iodine, $1.0 \mathrm{mg} ; 0,1.2 \mathrm{mg}$, Cu, 10mg, Fe; $20 \mathrm{mg}$.

Experimental Birds and Design: Two hundred and twenty five (225), 4 week-old broiler chicks (Anak strain ) were procured from Obasanjo Farms Limited Ogun State , Nigeria. The birds were divided into five groups of forty five (45) birds each and randomly assigned to the five treatment diets in a Completely Randomized Design (CRD). Each group was further sub-divided into three replicates of fifteen birds each and housed in a deep litter compartment measuring $6.0 \mathrm{~m} \times 4.0 \mathrm{~m}$. Feed and water were provided adlibitum and other routine poultry management practices maintained.

Blood Sample Collection: At the end of the 3 weeks feeding trials, two birds were randomly selected from each replicate, starved of feed overnight but not water. From the selected birds, $10 \mathrm{ml}$ blood sample was collected from each bird through the wing vein with a $10 \mathrm{ml}$ sterile syringe.

The blood so far collected was used for assessment of haematological indices and serum biochemistry studies. $5 \mathrm{ml}$ of blood samples were collected into Bijon bottles containing ethylene diamine tetraacetic acid (EDTA) as the anti-coagulant.

These were used for haematological assay. The remaining $5 \mathrm{ml}$ of blood samples were collected into the vial bottles (without anti-coagulant) and was allowed to coagulate to produce sera used for serum biochemical analysis. The blood samples collected were taken to the laboratory for haematological assessment (Campbell, 1988) such as Packed cell volume (PCV), Red blood cell (Erythrocyte) count (RBC), Mean cell volume (MCV), Mean cell Haemoglobin $(\mathrm{MCH})$, Mean cell Haemoglobin concentration $(\mathrm{MCHC})$, Haemoglobin $(\mathrm{Hb})$ and white blood cell (leukocyte) count. For serum biochemistry, the following were determined; total serum protein, serum albumen, serum globulin, serum urea, serum glucose, serum creatinine and serum cholesterol.

\section{RESULTS}

The summary of the results on the effects of varying levels of tigernut diets on the haematology and serum biochemistry of broiler finishers are presented on tables 5 and 6 respectively.

Table 5. Haematological characteristics of experimental broiler finisher

\begin{tabular}{|c|c|c|c|c|c|c|}
\hline PARAMETERS & $\begin{array}{l}\text { Dietary } \\
0 \%\end{array}$ & $\begin{array}{l}\text { Levels } \\
25 \%\end{array}$ & $50 \%$ & $75 \%$ & $100 \%$ & SEM \\
\hline Pack cell volume (\%) & $30.30^{\mathrm{a}}$ & $32.00^{\mathrm{a}}$ & $28.70^{a b}$ & $25.70^{b}$ & $24.30^{\mathrm{b}}$ & 0.63 \\
\hline Haemoglobin $(\mathrm{g} / \mathrm{dl})$ & $9.10^{\mathrm{ab}}$ & $9.60^{\mathrm{a}}$ & $8.80^{b}$ & $7.90^{\mathrm{C}}$ & $7.80^{\circ}$ & 0.19 \\
\hline Red blood cells $\left(\times 10^{6} \mu \mathrm{l}\right)$ & $2.41^{\mathrm{a}}$ & $2.33^{a}$ & $2.13^{\mathrm{a}}$ & $1.67^{b}$ & $1.43^{b}$ & 0.26 \\
\hline White blood cells $\left(\times 10^{6} \mu l\right)$ & $10.80^{\mathrm{a}}$ & $33.20^{\mathrm{C}}$ & $25.20^{\mathrm{b}}$ & $36.40^{\mathrm{d}}$ & $38.80^{\mathrm{d}}$ & 1.13 \\
\hline Mean cell volume (fl) & $159.10^{\mathrm{a}}$ & $124.30^{\mathrm{b}}$ & $119.90^{b}$ & $115.80^{\mathrm{C}}$ & $117.30^{\mathrm{C}}$ & 0.52 \\
\hline $\begin{array}{l}\text { Mean cell Haemoglobin } \\
\text { concentration }(\%)\end{array}$ & $33.30^{\mathrm{a}}$ & $33.30^{\mathrm{a}}$ & $32.60^{\mathrm{a}}$ & $30.90^{b}$ & $35.40^{C}$ & 0.09 \\
\hline Mean cell haemoglobin $\left(\mathrm{p}_{\mathrm{g}}\right)$ & $36.60^{\mathrm{a}}$ & $38.40^{\mathrm{b}}$ & $36.50^{\mathrm{a}}$ & $38.50^{b}$ & $36.30^{\mathrm{a}}$ & 0.01 \\
\hline Neutrophil (\%) & $4.20^{\mathrm{a}}$ & $7.00^{\mathrm{C}}$ & $4.00^{a}$ & $3.00^{b}$ & $1.00^{\mathrm{d}}$ & 0.74 \\
\hline Lymphocytes (\%) & $53.00^{\mathrm{a}}$ & $91.00^{b}$ & $86.00^{b}$ & $97.00^{\mathrm{C}}$ & $97.00^{\mathrm{C}}$ & 1.45 \\
\hline Eosinophils (\%) & 0.00 & 1.00 & 0.00 & 0.00 & 0.00 & 0.01 \\
\hline Monocytes (\%) & 0.00 & 1.00 & 0.00 & 0.00 & 0.00 & 0.01 \\
\hline Basophils (\%) & 0.00 & 0.00 & 0.00 & 0.00 & 0.00 & 0.00 \\
\hline
\end{tabular}

${ }_{\text {abcd }}$ mean within rows with different superscripts are significantly different $(P<0.05)$.

$\mathrm{SEM}=$ Standard Error Mean 
Agric. Biol. J. N. Am., 2013, 4(3): 186-191

Table 6 : Serum biochemistry of broiler finishers fed experimental diets

\begin{tabular}{|l|c|c|c|c|c|}
\hline & \multicolumn{5}{|c|}{ Dietary levels } \\
\hline Parameters & $\mathbf{0 \%}$ & $\mathbf{2 5 \%}$ & $\mathbf{5 0 \%}$ & $\mathbf{7 5 \%}$ & $\mathbf{1 0 0 \%}$ \\
\hline Total Protein (g/dl) & $44.30^{\mathrm{a}}$ & $39.3^{\mathrm{b}}$ & $37.00^{\mathrm{b}}$ & $35.80^{\mathrm{c}}$ & $30.30^{\mathrm{d}}$ \\
\hline Albumin (g/dl) & $2.56^{\mathrm{a}}$ & $2.44^{\mathrm{a}}$ & $2.46^{\mathrm{a}}$ & $1.98^{\mathrm{b}}$ & $2.09^{\mathrm{b}}$ \\
\hline Globulin $(\mathrm{g} / \mathrm{dl})$ & $1.70^{\mathrm{ab}}$ & $1.80^{\mathrm{b}}$ & $1.60^{\mathrm{a}}$ & $1.60^{\mathrm{a}}$ & $1.40^{\mathrm{c}}$ \\
\hline Creatinine (mg/dl) & $54.00^{\mathrm{a}}$ & $61.00^{\mathrm{b}}$ & $66.00^{\mathrm{c}}$ & $65.00^{\mathrm{c}}$ & $62.00^{\mathrm{b}}$ \\
\hline Urea (mg/dl) & $4.40^{\mathrm{a}}$ & $4.60^{\mathrm{a}}$ & $4.90^{\mathrm{b}}$ & $4.90^{\mathrm{b}}$ & $4.90^{\mathrm{b}}$ \\
\hline Cholesterol $(\mathrm{mg} / \mathrm{dl})$ & $3.33^{\mathrm{a}}$ & $3.33^{\mathrm{a}}$ & $3.34^{\mathrm{a}}$ & $3.33^{\mathrm{a}}$ & $3.33^{\mathrm{a}}$ \\
\hline Total Bilirubin $(\mathrm{mg} / \mathrm{dl})$ & $6.50^{\mathrm{a}}$ & $6.50^{\mathrm{a}}$ & $6.50^{\mathrm{a}}$ & $6.50^{\mathrm{a}}$ & $6.50^{\mathrm{a}}$ \\
\hline
\end{tabular}

${ }^{a b c d}$ means within rows with same superscripts are not significantly different $(P>0.05)$.

Mean cell volume (MCV). The mean cell values obtained were 159.10, 124.30, 119.90, 115.80 and

Packed cell volume (PCV): The packed cell volume of the finisher broilers were $30.30,32.00$, $28.70,25.70$ and 24.30 for $0 \%, 25 \%, 50 \%, 75 \%$ and $100 \%$ dietary treatments respectively. The result revealed significant differences between treatment groups $(P<0.05)$.The highest value of 32.00 was recorded from birds fed $25 \%$ tigernut based diets but was not significantly different $(P>0.05)$ from PCV value obtained from the control group fed $0 \%$ tigernut diet. Nevertheless, the least value $(24.30 \%)$ was obtained from broiler finisher fed $100 \%$ tigernut based diets, though there was no significant difference in value obtained from $75 \%$ dietary treatment $(P>0.05)$.

Haemoglobin (HB):- The highest value of 9.60 was recorded from $25 \%$ group, while $0 \%, 50 \% 75 \%$ and $100 \%$ groups have values of $9.10,8.80,7.90$, and 7.80 respectively, indicating significant differences among the treatment groups $(P<0.05)$.

Red blood cells (RBC):- There were no significant differences between broiler finisher birds fed control (0\%), 25\% and $50 \%$ tigernut diets but these were significantly different $(P<0.05)$ from groups fed $75 \%$ and $100 \%$ tigernut based diets. The RBC values were $2.41,2.33,2.131 .67$ and 1.43 for $0 \%, 25 \%$, $50 \% 75 \%$ and $100 \%$ dietary treatment respectively.

White blood cells (WBC):- The WBC values were $10.80,33.20,25.20,36.40$ and 38.80 for $0 \%, 25 \%$, $50 \%, 75 \%$ and $100 \%$ dietary tigernut inclusion respectively,showing significant differences among the treatment groups $(\mathrm{P}<0.05)$. The lowest value of 10.80 was obtained from the control $(0 \%)$ group while the highest value of 38.80 was recorded at $100 \%$ dietary inclusion.
$117.30 \mathrm{fl}$ for birds on diets $0 \%, 25 \%, 50 \%, 75 \%$ and $100 \%$ inclusion levels respectively. Thus, there were significant differences $(\mathrm{P}<0.05)$ among the treatment groups. The highest value was obtained from the control group while least value was recorded from birds fed $100 \%$ tigernut diet.

Mean cell haemoglobin concentration (MCHC): The $\mathrm{MCHC}$ values were 33.30, 33.30, 32.60, 30.90 and $35.40 \%$ for birds on groups $0 \%, 25 \%, 50 \%, 75 \%$ and $100 \%$ tigernut diets respectively. There was no significant difference $(P<0.05)$ between groups fed diets containing tigernut at $25 \%, 50 \%$ and $0 \%$ (control) but were significantly different from birds fed $75 \%$ and $100 \%$ tigernut diets $(P<0.05)$.

Mean cell haemoglobin (MCH): The figures obtained were $36.60,38.40,36.50,38.50$ and $36.30 \mathrm{pg}$ for broiler finishers fed diets containing $0 \%$, $25 \%, 50 \%, 75 \%$ and $100 \%$ inclusion of tigernut respectively. From the above, there was no significant difference $(P>0.05)$ between birds fed control $(0 \%)$, $50 \%, 100 \%$ diets, all of which were significantly lower $(\mathrm{P}<0.05)$ than those of groups on $25 \%$ and $75 \%$ dietary levels.

Neutrophil: The neutrophil values were 4.20, 7.00, $4.00,3.00$ and $1.00 \%$ for birds on diets $0 \%, 25 \%$, $50 \%, 75 \%$ and $100 \%$ inclusion respectively. There was significant difference among the treatment groups $(P<0.05)$.

Lymphocytes: The lymphocyte values of experimental birds were 53.00, 91.00, 86.00, 97.00 and 97.00 for birds fed diets containing tigernut at $0 \%, 25 \%, 50 \%, 75 \%$ and $100 \%$ levels of inclusion respectively. There was a significant difference between birds on control group and those fed tigernut based diets $(\mathrm{P}<0.05)$. 
Agric. Biol. J. N. Am., 2013, 4(3): 186-191

Serum biochemistry of broiler finishers fed tigernut based diets: Total protein: The total serum protein concentrations were 44.30, 39.3037 .00 , 35.80 and $30.30 \mathrm{~g} / \mathrm{dl}$ for birds fed diets $0 \%, 25 \%$, $50 \%, 75 \%$ and $100 \%$ respectively. The serum protein in the diets decreased as level of tigernut increased. However, there was significant difference between the birds in control group and those fed the tigernut diets $(\mathrm{P}<0.05)$.

Serum albumin: The concentration of serum albumin obtained were 2.56, 2.44, 2.46, 1.98 and $2.09 \mathrm{~g} / \mathrm{dl}$ for dietary treatments $0 \%, 25 \%, 50 \%, 75 \%$ and $100 \%$ respectively. The serum Albumin concentration was highest in the control group while the least value of 1.98 was obtained from birds fed $75 \%$ tigernut diet. There was no significant difference between the serum albumin of birds on $75 \%$ and $100 \%$ levels of inclusion ( $P>0.05)$, both of which were significantly different from the control group. $(\mathrm{P}<0.05)$.

Globulin: The values of $1.70,1.80,1.60,1.60$,and $1.40 \mathrm{~g} / \mathrm{dl}$ were obtained for $0 \%, 25 \%, 50 \%, 75 \%$ and $100 \%$ dietary levels respectively. There was no significant difference among the treatment groups $(P>0.0 .5)$. except the group fed $100 \%$ tigernut based diet which was significantly different from the other dietary treatments $(\mathrm{P}<0.05)$.

Creatinine: There were significant difference $(P<0.05)$ in creatinine concentration among the treatment groups. The values of $54.00,61.00,66.00$, 65.00 and $62.00 \mathrm{mg} / \mathrm{dl}$ were obtained from birds on dietary treatments $0 \%, 25 \%, 50 \%, 75 \%$ and $100 \%$ respectively. The lowest value was recorded from the control group.

Urea: The Urea values of the groups were 4.40 , $4.60,4.90,4.90$, and $4.90 \mathrm{mg} / \mathrm{dl}$ for $0 \%, 25 \%, 50 \%$, $75 \%$ and $100 \%$ tigernut inclusion levels. There was no significant difference between values obtained from control group $(P>0.05)$ and birds fed $25 \%$ tigernut diet. However, there were significant differences $(P<0.05)$ among birds fed $0 \%$ and $25 \%$ tigernut diets and those birds fed tigernut at $50 \%$, $75 \%$ and $100 \%$ inclusion levels.

Cholesterol: There was no significant difference $(P>0.05)$ among the treatment groups. The values of $3.33,3.33,3.34,3.33$ and $3.33 \mathrm{mg} / \mathrm{dl}$ were obtained from birds fed tigernut at $0 \%, 25 \% 50 \%, 75 \%$ and $100 \%$ dietary levels.

Total bilirubin: - The Bilirubin concentration of the experimental birds were $6.50,6.50,6.506 .50$ and $6.50 \mathrm{mg} / \mathrm{dl}$ for $0 \%, 25 \%, 50 \%, 75 \%$ and $100 \%$ dietary inclusion of tigernut. There was no significant difference $(P>0.05)$ among the treatment groups.

\section{DISCUSSION}

Haematology and Serum biochemistry of finisher birds: The packed cell volume (PVC) values obtained from this study indicated that the concentration is inversely proportional to the dietary inclusion of tigernut in diets of the finisher birds. The highest value was obtained from the birds fed control diet, which decreased with increased replacement of tigernut. The poor values $(p<0.05)$ in PCV of birds fed diets containing tigernut meal especially beyond $50 \%$ level which consequently had values below the recommended range of $30-40 \%$ (Siegmund, 1979; Justin, 2010) may be attributed to the anti-nutrients of raw tigernut meal such as trypsin inhibitors, tannins, phytate, among others, that inhibit proper utilization of nutrients especially protein and iron necessary for red blood formation (Ayuk and Essien, 2009). Similar report was obtained when raw Jackbean diets were fed to African catfish (Osuigwe et al., 2005).

Nevertheless, the reductions in haemoglobin and red blood cell counts which significantly $(P<0.05)$ differed in birds fed tigernut diets beyond $50 \%$ dietary levels could also be due to high fibre content of tigernut coupled with the anti-nutritional inhibitors particularly the phytate that chellates divalent metals utilization in monogastric animal metabolism; these conditions above, might have been responsible for higher values of white blood cells in diets containing tigernut far above the control as was shown in this study (Akinwuntimi et al., 2004; Obidinma, 2009).

However, the lymphocytes values in broiler finishers were higher in all the tigernut treatments compared to control $(P<0.05)$. This was due to the stress of antinutrients and high fibre diets on broiler chicks which often cause reduction in oxygen carrying capacity of the animals blood i.e. anaemia with the resultant impairment on growth (Aduloju, 2000; Mohammed and Oloyede, 2009) as shown by the finisher broilers at the various replacements levels.

The serum biochemistry of the finisher birds revealed that total protein, albumin and globulin concentrations reduced as the dietary levels of tigernut increased in the diets. These showed that tigernut meals were poorly utilized by the broilers at relatively higher dietary inclusion. Also, the effect of feeding high dosage of tigernut which contained relatively high fibre compared with maize perhaps, was the reflection of high creatinine values $(p<0.05)$ between the control group and birds fed diets containing tigernut meal. The high creatinine values in the 
serum indicated poor utilization of nutrient due to muscles wastage (Udoyong et al., 2010).

The overall poor haematological and serum characteristics of finisher broilers fed diets containing tigernut meal particularly beyond $50 \%$ dietary inclusion were indication of poor nutrient utilization of such diets. Similar reports were obtained when catfish was fed poultry litter (Omitoyin, 2006).

\section{REFERENCES}

Aduloju, Y.O (2000). Blod composition of broiler chicks fed raw or processed full-fat soybeans supplemented with Saccharomyces cerevisae .BSc Thesis, Dept. of Anim. Prod. Unilorin, Nigeria.

Akinwutimi, A.H., Oke .U.K. and Basiekong .S.F.A (2004). Observation on blood constituents of broiler Finisher birds fed toasted lima bean (Phaseolus lunatus ). In : proc. $9^{\text {th }}$ Ann.Conf. ASAN sept $13^{\text {th }}-16^{\text {th }}, 2004$. Eboyi State University, Abakaliki. 60-67 .

A.O.A.C.(1995) Official methods of Analysis. Association of Official Analytical Chemists (ed. K. Herrick) $16^{\text {th }}$ ed. Washington D.C. U.S.A.

Ayuk, E.A and A . Essien (2009). Growth and haematological response of broiler chicks fed graded levels of sweet potato (Ipomea batata) meal as replacement for maize. International Journal of Poultry Science. $8(5): 485-488$.

Campbell T. N. (1988). Avian Haematology and Cytology. lowa State Univ. Press, USA

David D.L. (2009). Effects of anti-nutritional factors of tiger nuts (Cyperus esculentus L) and soybeans (Glycine Max L) on growing rabbits. Bioscience Research Communications. 21(5): 241-247

Emenalom, O.O.., Esonu, B.O., Etuk, E.B. and Anaba C. (2009). Effect of Mucuna pruriens (Velvet Bean) leaf meal on performance and blood composition of finisher broiler chickens. Nig. J. Anim. Prod. 36(1): 52-60

Ezeri, G. N. O. (2001). Haematology response of Clarias gariepinus to bacterial infection and prophylactic treatment with antibiotics. J. Aqua. Sci. 16: 22-24
Joshi P. K., Bose M. and Harish D. (2002). Changes in certain haematological parameters in a siluroid catfish Clarias batrachus (Linn) exposed to cadmium chloride. Pollution Resources 21(2): 119-122.

Justin, C.A .(2010): Nutritional evaluation of mixture of fermented bovine blood and Digesta for broiler birds and laying hens. PhD Thesis, Dept of Animal science and Technology, Federal University of Technology, Nigeria.163p

Mohammed, N.O and Oloyede .O.B (2009). Haematological parameter of broiler clicks fed Aspergillus niger fermented Terminalia catappa seed meal - based diet. Global journal of Biotechnology and Biochemistry. 4(2): 179-183.

Obidinma. V.N. (2009). Brewer's spent grain as energy source in finisher broiler birds and laying hen production. PhD. Thesis, Imo State University, Owerri, Nigeria.

Oladele A.K., Oshundahunsi F.O. and Adebowale A.Y. (2009). Influence of processing techniques on the nutrients and anti-nutrients of tiger nut (Cyperus esculentus). World Journal of Dairy and Food Sciences, 4(2): 88-93.

Omitoyin, B.O. (2006). Haematological changes in the blood of Clarias gariepinus (Burchell 1822) juvenile fed poultry litter. Livestock Research for Rural Development. 18(11):1-6.

Osuigwe, D.I., Obiekezie. A.I and Onuoha.G.C (2005). Some haematological changes in hybrid catfish (Heterobranchus longofilis x Clarias gariepinus) fed different dietary levels of raw and boiled jackbean (Canavalia ensiformis ) seed meal. African Journal of Biotechnology. 4(9): 1017-1021

Siegmun, O.H. (1979): Editor veterinary manual, $5^{\text {th }}$ Edition. 21p.

Udoyong, A.O; A. Kibon, S.M. Yahaya, B. Yakubu, C. Augustine and L. Isaac (2010). Haematological Response and serum Biochemistry of Broiler chicken fed graded levels of enzyme (maxigrain) supplemented cassava peel meal (CPM) based diets. Global Journal of Biotechnology and Biochemistry 5 (2): 116- 119 